\title{
Influence of Project Implementation Strategies by Religious Organizations on Rural Development: A Case of Kitui Catholic Diocese, Kitui County, Kenya
}

\author{
Antony Musyoki Mbandi and Mary Nyawira Mwenda
}

\section{ABSTRACT}

It has been documented that religious institutions have influenced the development of education systems, health facilities, infrastructure such as roads, water provision structures and even building designs. This study sought to find out the influence of project implementation strategies by religious organisations on rural development in Kenya. The study focused on the Catholic Diocese of Kitui, in Kitui County and sought to document how project implementation strategies by Catholic Diocese of Kitui influence rural development in Kitui County of Kenya. The target population for this study was drawn out of a homogenous setting of Kitui County, Kitui East Subcounty, Nzambani and Chuluni wards and covered a total of 6939 households. The study covered a sample population of 364 out of the determined target population of 6939 households. The analysis of the data collected was done using Statistical Package for Social Sciences (SPSS) software. The study established that project implementation strategies by Catholic Diocese of Kitui influenced rural development in Kitui County as shown by a composite mean of 3.945. The Chi-Square test results of the association between project implementation strategies by religious organizations and rural development at Catholic Diocese of Kitui, Kitui County in Table 16, shows a Chi-Square value $=8.954, p=0.003$. The p-value is less than 0.05 and hence there is a statistically significant association between project implementation strategies and rural development at Catholic Diocese of Kitui. From the findings, the study found that if the independent variable, project implementation strategies, was held constant at zero, then the rural development in Kitui County will be 3.537. The study also found that a unit change in project implementation strategies changes would lead to a 0.843 unit change in rural development in Kitui County. The variable was significant since $p$-value $=0.012<0.05$. The study concluded that project implementation strategies had a great influence on rural development in Kitui County. The study recommends that there is need for capacity development to identify resource availability and build capacities in communities and have them assisted to undertake church based projects. The study recommends that there is need for capacity development to identify resource availability and build capacities in communities and have them assisted to undertake church based projects. To create more ownership of the projects, the study recommends that there should be involvement of user representatives from the initiation to the implementation phases of the projects.

Keywords: Project Implementation Strategies, Religious Organizations, Rural Development, Development projects.
Published Online: January 11, 2021

ISSN: $2507-1076$

DOI: $10.24018 /$ ejbmr.2021.6.1.673

Antony Musyoki Mbandi*

University of Nairobi, Kenya.

(e-mail: musyokimbandi@gmail.com)

Dr Mary Nyawira Mwenda

Kenya.

(e-mail: mmwenda@uonbi.ac.ke)

*Corresponding Author

\section{INTRODUCTION}

The origins of the terminology rural development can be traced back to the United States of America which implemented a rural development programme and also developed rural development laws. In India, rural development was first coined in the late 1950s, early 1960s. A research done by [11] on evolution of the concept and policy of rural development with emphasis in its early years (1955-1980), states that the genesis of rural development is different depending on level of economic status of a country. The former rural development concepts were focused on combating poverty with a strong agricultural component while in later years it was viewed more as a mechanism to reduce the imbalance between urban growth and rural growth. It led to a diversification from agrarian thinking to economic diversification [11].

Today the concept of rural development has remained with this conceptual thought of diversification of income sources and has been added with provision of services at the rural level that are equitable to the urban setting. This includes provision of energy for production, road networks, 
development of industries at the local level, decentralization of government hence spurring local economy and many other aspects of economic engagement. [2] in their research, innovation programs are working for the poor suggest that the majority of the poor still live in rural areas in developed countries, most of which are dependent on agriculture and rural jobs and livelihoods activities. We also conclude that knowing the characteristics of innovation by policy makers and program managers can help them identify opportunities and change the factors that help the disadvantaged innovate. The model utilized by China over the last 20 years has seen the country grow to the second position economically in the world through providing opportunities and services at the rural setting hence enabling the rural folk to grow their socio-economic space.

The approach in countries such as China has been taunted as the best way to stem migration to urban areas leading to congestion and over utilization of resources due to people congregating in a small area. China's "No. 1 Central Document" is the planning document of the government of China. The current document, which was released on February 19, 2019, outlines the priorities as development of agriculture in rural areas. The document highlights poverty elimination in the whole of China by 2020, optimize agricultural supply, build on agricultural technology, grow international agricultural trade, improve the living standards in the rural areas and build rural industries. It has also been established that the current immigration crisis in developed countries can be traced back to lack of meaningful development in rural settings in various countries that are developing.

In their research, [20]. states that rural development comprises development programmes and initiatives intended for enhancing living standard of the rural dwellers. The initiatives are usually taken by local authorities, local and international donor agencies, and related nongovernmental organizations. They go on to indicate that although rural development is agreed to be much more extensive than agricultural innovations as some of the other rural development activity replaces agriculture, and also promotes alternative income tools and means of survival of rural poor people. Rural development is also the most important occupation for large rural people in Africa. As a whole, agricultural development could still serve as a main contributor of rural growth up to the present time, and that agricultural development continues to significant role in poverty reduction. This makes the Chinese approach plausible.

The countries that are experiencing people leaving are in Eastern Europe, Middle East, Africa, and South America. [16], speaks to the failing policy of stemming the problem of immigration to Europe through impactful rural development programmes at the source of the immigrants. Looking at the countries that the people are heading to, there is a main pattern of early development being linked to religious organizations. An example is Germany where even the state was collecting a tax on behalf of religious organizations in recognition of the social work that they were undertaking. The United States of America also has a long history of religious organizations undertaking charity work. These include the Jewish society, Evangelical institutions, Protestant churches and the Catholic church.

These religious organizations see development as part of their social service within the global charity work targeting orphans and widows, prisoners, the sick and needy of every kind. For the Catholic church, this is essential to her ministry and can be traced back to the $4^{\text {th }}$ Century in Egypt with the establishment of 'diaconia', meaning, the institution within which monastery responsible for all works of relief, that is to say, for the service of charity. Throughout the world the church through her many arms has fostered this charity work for the social development of humanity. [19], examines the role of Christian churches in national politics in Ghana. It draws on various forms of data: a 1994 survey questionnaire, in-depth interviews, and content analysis of existing data. A total of 355 responses were received on the survey while 110 people were interviewed on a variety of church and political issues. Respondents were drawn from Catholic and Protestants denominational backgrounds. The preliminary results of the study lend support to the view that since the 1980's, Ghanaian Christians have been more actively involved in politics than ever before. These findings have important implications for the role religion plays in political development in Ghana. It is also significant to note that politics and development are very closely intertwined.

In the region the religious organizations have been involved in rural development with a majority of schools and hospitals being established and run by religious organizations across the continent. Quoting the former Representative of World bank in Kenya, Mr. Makhtar Diop, "the Catholic Church was very instrumental in establishing social centers in Senegal when I was growing up and this was very important for us youth as points for gaining mentorship and coaching". It is not only the Catholic church that had such centers and facilities across Africa. In the East African region, we have institutions such as Compassion which is a religious organization has provided learning to many youths through scholarships locally and abroad. In the Kenyan context, religion and development have been seen to be synonymous especially in the rural setting. This has been the case since the arrival of missionaries who introduced what was then termed as modern education, medicine and other social as well as economic aspects of development. The thought promoted by historians is that missionaries presented the 'African ways and traditions as uncivilized and not developmental in nature' to bring about colonization. On numerous occasions this has caused friction in some quarters with outright rejection of religion or the acceptance of religion with a view of individual gain. The common perception has been that the establishment of a mission centre has led to the economic development of a region.

The social dimension of poverty is manifested in lack of basic needs, food, clean water, health, shelter, and education together with the inability to engage in productive activities. The social economic consequence of poverty permeates the entire society afflicting even the well off, such that not even the wealthy are able to live in peace and comfort where widespread poverty exists [6]. Rural areas are the potential of a given country's development. They are 
endowed with resources which if well utilized transforms a region positively. Failure to implement appropriate policies leaves the rural areas undeveloped so that they are not beneficial to the dwellers causing rural urban migration.

Rural areas are often marginalized leaving little opportunity for the poor to influence government policies, including policies regarding what to produce and how to do it. A combination of these and other factors results in high incidence of poverty and low levels of economic development as manifested in low income, illiteracy, malnutrition among others. To alleviate poverty, integrated rural development agencies such as the Catholic Church strategies have been attempted in Kenya to spur development in rural areas where the majority of poor people live.

However, poverty levels vary by regions, countries, and socio-economic characteristics of households. To address these disparities and to take advantage of the uniqueness of the natural endowments in each region, decentralized rural development strategies have been devised and employed. A good example is the rural development programmes that have been implemented by Kenya and various moments since independence. Between 1980 and 2000, the Kenyan government in collaboration with the German government implemented rural development projects in Samburu, Transmara, Marsabit, Lamu, Mwingi and Kilifi in an effort to bring about comprehensive change at the local level. The projects which were actually implemented in a multiple year programme, aimed at providing education, health, roads, water, shelter, security, settlement, environmental management, and any aspect of community development that would be identified as a need for them to develop. Needless to say, this approach had its successes but also proved very expensive to implement. Looking back at these projects, the successes did not create the permanent change that was expected with a major drawback of political interference, lack of community participation and lack of adequate finances to sustain gainful development. The development levels in the mentioned areas remains wanting with communities still languishing in poverty. On their part, religious organizations have been implementing similar projects but not just because of availability of funding which will eventually come to an end, but as part of their existence in the community. A good example is the development that took place around Thogoto, Kikuyu, which was all encompassing or Mathari in Nyeri. In these two examples, religious organizations have existed in the same space for over one hundred years and continue to offer developmental services to the community. This probably is what gives religious organizations an edge in delivering impactful rural development.

Therefore, this study sought to determine the influence of project implementation process by religious organizations in rural development in Kenya, a case of the Catholic diocese of Kitui, Kitui County. The Catholic Diocese of Kitui covers Kitui County, which is located in Eastern Province of Kenya. Kitui County is about 180 kilometers from Nairobi (Kenya's capital City) at its nearest point and borders Tharaka County to the north, Taita/Taveta County to the south, and Machakos and Makueni Counties to the west and Tana River County to the east. The total County area is about $30,496.5 \mathrm{KM}^{2}$ including $6,290.3 \mathrm{KM}^{2}$ at the southern end of the county, which is occupied by the Tsavo East National Park.

\section{A. Statement of the Problem}

Rural areas are the potential of a given country's development. They are endowed with resources which if well utilized transforms a region positively. In Kenya the scenario is different in that the strategies adopted have not been successful in accelerating rural development in order to alleviate poverty despite the publicity and efforts put in place in their implementation. On the other hand, religious organizations and early missionaries have been taunted to be the originators of any meaningful rural development that has taken place in Kenya especially in the early days after independence.

Beyond this initial growth, the focus on government institutions and structures to achieve rural development, have enabled central bureaucracy to retain effective power and serve to alienate rural people rather than bringing them into the development process. This is also being evidenced in our newly created governance structures with the creation of counties, which have effectively brought centralization closer to the people with county governments holding communities' ransom. Consequently, poverty levels still remain high and social profiles still show that poverty is concentrated among small farmers, pastoralists, unskilled workers and families that are rural based. Religious organizations and especially the Catholic Church have been seen and known to be actively involved in the process of bringing development to the people while admonishing the centralized approach to development through the principle of subsidiarity. [12] states that the Honduran Catholic Church played a crucial role in pushing for radical reform during the 1960s, well before its counterparts in Latin America. In neighboring Nicaragua, Church policy bolstered the Somoza regime, changing only with the emergence of revolution in the 1970s. The Catholic Church played markedly different roles in Nicaragua and Honduras prior to 1979. Much of this contrast is best explained in reference to state structures and their relationship to the Church. [8] had followed a strongly centralized development planning strategy since independence in 1963 but in 1983 a new approach called District Focus was introduced. The paper considered the potential of that approach to bring about meaningful change to the rural population using a case study from Murang'a District. Inequalities between socioeconomic strata as well as within the household had increased since 1963 and it was argued that post-independence modes of local organization were directly related to these inequalities. Although District Focus had the theoretical potential for addressing these issues and for supporting initiatives in local organization such as those by women described in the paper, the authors argued that this was unlikely to occur. District Focus was a centralization in a new guise. The paper argued for a "development from within" approach as a response to the current crisis in rural Africa.

While such studies have been conducted on government and donor supported endeavors such as District Focus for Rural Development (DFRD) and Special Rural 
Development Programmes (SRDPs), there is has not been much study and data on the impact of the influence of project implementation by religious organizations on rural development in Kenya and specifically the case of Catholic Diocese of Kitui, in Kitui County. This study therefore sought to find out and document the role of religious organizations in meaningful rural development with a focus on the Catholic Church in Kitui County and serves to inform society on the influence of project implementation by religious organizations on rural development in Kenya looking at Catholic Diocese of Kitui in Kitui County. The study sought to address the empirical evidence gap and will specifically examine the influence of project implementation strategies by religious organizations on rural development, a case of Catholic Diocese of Kitui in Kenya.

\section{B. Objective of the Study}

To examine the influence of project implementation strategies by Catholic Diocese of Kitui on rural development in Kitui County, Kenya.

\section{LITERATURE REVIEW}

\section{A. Rural Development in Kenya}

Rural development has been defined as a growth strategy for a particular target population, the rural poor that involve extending the benefits of development to those whose futures lie in the pursuit of a livelihood in rural areas [18]. As high rates of poverty are found in certain regions and social groups, targeting rural development in such areas and groups would be/is a cost effective way of reducing and alleviating poverty in those areas. Governments and policy makers have therefore the challenge of formulating policies and strategies that reduce poverty by coming up the development plans that focus on regions where the poor live.

Concern over the high level of rural poverty led donor agencies to develop specific interventions aimed at rural areas. The most recent of which was the integrated rural development model. Through its Area Development Projects, the World Bank attempted to target the rural poor by providing a detailed, multi-sectoral package for rural development. However, poor project performance and the failure to bring about a sustained improvement in the living standards of rural people led to a significant reduction in the number of Area Development Projects and the abandonment of the approach to rural development. Integrated rural development programs typically contained similar components and emphasized increased agricultural productivity as the basis for raising rural incomes, while recognizing the synergistic contribution of better education, health, and other basic services to further improvements in people's quality of life and their overall productivity. Projects were sometimes based on single agricultural products accompanied by other services that received a much smaller proportion of project funds, e.g., tea in Kenya [5].

According to a research undertaken by [5] in 2001 on failures of the rural development policies, a number of factors were found to contribute to the lack of success of the said policies. For example, government line agencies were perceived as inefficient, technically incompetent, understaffed and philosophically conservative and unable to implement the necessary programmes. Dissatisfaction with their performance as program-implementing agencies led administrators to advocate the creation of new autonomous implementation units designed to by-pass the line agencies. However, experience suggests that almost nowhere have these new administrative units been able to survive in the local political and bureaucratic establishment. In addition, financial arrangements for implementing rural development programmes were also problematic and characterized by excessive delays in the release of funds and lack of counterpart funding from local agencies, both of which severely retarded project implementation.

In other situations, sub-projects for rural development were usually small, often quite simple, and always widely dispersed. Central planning for hundreds of differentiated projects and localities was likely to fail because of the location-specificity of conditions and needs. Furthermore, access to the higher decision-making levels of government and the administrative freedom to tailor programs precisely to local conditions were frequently sacrificed for administrative convenience when projects were generalized. Highly centralized administration of national programs made it difficult to carry out the experiments with program content and delivery methods that were essential if rural development programs were to meet the diverse needs of these areas [5]. Further to advance the need for need for proper project implementation, [21] found out that in Northeast Brazil, despite sustained efforts to reduce rural poverty and more than $\$ 3.2$ billion in spent, the rural poor were little better off than they were two decades earlier. The findings further established that Brazil's difficult macroeconomic environment had tended to restrict the amount of funds available for rural development and additionally project implementation had often been seriously undermined by the excessive centralization of decision-making in Brazil prior to the approval of a new constitution in 1988 .

According to a research done by [5], the failure of integrated rural development models left experts involved in rural poverty reduction, in confusion. As a result, the World Bank has retreated from the ambitious agenda of the 1970s into the support of more traditional sector-specific programs or projects, each dealing with a specific component of rural development, such as agricultural extension, small-scale irrigation, and rural roads. By withdrawing from an integrated approach to rural development, donors left the complexity and other implementation problems in the hands of the country governments. New approaches to rural development have been suggested with the most promising one is Medium Term Expenditure Framework (MTEF). According to [18], the MTEF process involves such main steps as, estimating project implementation strategies over the medium term, either a three or five-year period; prioritizing projects and programs in a ranked manner to facilitate selection of the best option; estimating the actual costs of existing government policies programs, and targets in each sector; and lastly putting the information together in an expenditure 
framework as the basis for making decisions on how resources will be allocated to the line ministries and what outcomes will be expected.

Thus, the Medium Term Expenditure Framework consists of a top-down resource envelope, a bottom-up estimation of the current and medium-term costs of existing policy, and, ultimately, the matching of these costs with available resources. Matching of costs should normally occur in the context of the annual budget process, which should focus on the need for policy change to reflect changing Macroeconomic conditions as well as changes in strategic priorities of the government. In this case the focus is budget sustainability, which avoids starting projects and programs, which do not get completed [18].

The main objective of the MTEF macroeconomic strategy is to create a favorable macroeconomic environment for private sector-led growth and to enhance improvement in public sector service delivery. While higher economic growth is a necessary condition for increasing employment and reducing poverty, specific policies and measures are needed to ensure that the benefits of growth are widely shared and that they will reach the poor. These are the key linkages between the Medium Term Expenditure Framework and the poverty reduction strategy. The Medium Term Expenditure Framework has the objective of addressing the weaknesses of macroeconomic management in order create an environment which would support efficient production, thereby attracting both foreign and domestic investment. Equally important is the need to improve public sector performance by concentrating resources on a focused range of activities to support a propoor growth strategy. A crucial element in the MTEF strategy is to determine the resource envelope available during the specific period, usually three years [18]. Three important steps in the process are making sure that projections are made on the likely growth pattern during the period, a prognosis has to be made on expected domestic revenue collected by the tax authorities, together with the sustainable debt resources and projections have been made on the amount of external aid or resources entering into the government budget.

Practical strategies have to be put in place to ensure that given the limited resources, hard choices, based on the top priorities, are made. Measures to shift funding from personal emoluments to operations and maintenance in the civil service are crucial. In a nutshell, political correctness should not be the criteria for allocating resources but rather, national priorities outlined in the country's development plans and strategies should form the basis for government expenditure. The success of this method in rural development lies in establishment of a legitimate institutional framework for rural development at the national, district and sub-district levels. According to a study conducted by [7], it is important to undertake an assessment and enhancement of institutional organizational capacity of government and stakeholders to effectively engage in resource allocation for rural development efforts. In his research, [15]), Development Needs and the Mobilization of Rural Resources in Highland Bolivia, he examined the development problems and the activities of two non-governmental organizations (NGOs) and a number of affiliated agencies in two representative regions of highland Bolivia: the northern Altiplano and the eastern Cordillera region in the Department of Cochabamba. Based on the documentation of the agencies and on numerous talks and formal interviews with representatives of the NGOs and the local farmers, an attempt was made to identify the major problems and constraints of specific micro-regions, as well as the perceived development priorities, and the strategies of the agencies and local communities to implement the development process. The study concluded that it is important to undertake appraisal, mobilization and use of resources to achieve development projections while keeping in mind that an effective framework for participatory development and evaluation needs to be negotiated in advance with both the funders and the recipients of the development effort.

As with other strategies, the root cause of policy failure is likely to be mainly due to lack of political will together with weak or absence of institutional framework to implement policies, and programs, monitor progress, and take corrective action in a timely fashion. Policy formulation has to adequately be consultative and inclusive and implementation has, in all cases, to be organized without policy reversals. People and their representatives have to influence decisions and allocation of resources and not to leave central government administrators as the sole decision makers, in pertinent matters at the national, local authorities, and community level.

[4] recommend that rural development can be achieved if key implementation and monitoring tasks are carried out properly. These tasks include ensuring that facilitating development of an institutional arrangement for people to identify their own priorities. Also, there should be establishment of a legitimate institutional framework for rural development at the national, district and sub-district levels. The institutions thus created should facilitate engagement between government, civil society, private sector and other stakeholders and ensure participation of poor and marginalized. An appropriate policy and legislative framework to ensure this has to be put in place. There should be an assessment and enhancement of the institutional and organizational capacity of government and stakeholders to jointly and effectively engage in rural development efforts. This should be geared towards ensuring that the institutions and organizations involved in the process demonstrate improved capacity to carry out development tasks and strategic partnerships with other stakeholders are developed. An appraisal, mobilization and use of government resources, both at national and local levels private sector and civil society resources should also be incorporated to achieve rural development. Support should also be lent to efforts to organize people around common interests to influence decision making and resource allocation. The analysis and dissemination of the development strategies to national and local levels should be done so as to empower people to understand and influence resource allocation and use [4]. [10] in their research titled, Factors Affecting the Effectiveness of Monitoring and Evaluation of Constituency Development Fund Projects in Kenya: A Case of Laikipia West Constituency Country: Kenya, established that the 
constituency development Fund (CDF) projects capacity building, monitoring and evaluation is vested on the constituency development Fund committee (CDFC) and the CDF board and allowed $2 \%$ of the allocation to be used for the purpose. Many people in Kenya did not agree on the achievement of CDF projects stated objectives hence the issue of its success. The study sought to establish the factors affecting monitoring and evaluation on (CDF) projects with reference to technical capacity, political influence, stakeholders' participation, and budgetary allocation of CDF projects in Kenya. The research recommended efficient monitoring and evaluation on CDF projects in order to achieve the intended objectives.

It is therefore crucial that intervention and implementation of an effective framework for participatory rural development with an effective monitoring and evaluation mechanism is done. This framework for participatory monitoring and evaluation should be established, engagement broadened, and information systems developed to ensure effectiveness. A regular evaluation of expenditure outcomes and taking corrective action when and where needed should be part of the implementation framework. Since centralized approaches have been unable to initiate sustainable development programs and projects in rural areas in less developed countries, there has been needed to employ decentralized approaches and strategies in rural development planning.

\section{B. Project Implementation Strategies and Rural Development}

The strategies of religious organizations are anchored on the presence an existence on the local communities. This means that religious organizations respond and work within the structures of the local communities to the large extent. They have also been known to be the originators of ideas that serve local needs. Religious organizations through these approaches to rural development have played a key role in the growth of the social enterprise and social business movements [14]. The first strategy that religious organizations use is getting the buy in of communities to the project. This is done through planning together with the community and identifying the critical needs. Religious organizations also undertake to ensure that they have the right expertise on board to ensure that the project is implemented successfully. Financial resources are also clearly identified and mobilized with clear targets and timing to ensure success of the projects. Measurement is also employed as a critical strategy in ensuring that the projects are successful.

The strategies that are employed by religious organizations are myriad and diverse in nature, but they do follow sound project implementation principles starting with clarity for purpose where the projects have to have clarity of purpose. This study sought to understand how well the clarity of projects is defined so as to deliver rural development. A second aspect is the experience of previous projects. Learning and building from previous projects is a strategy that is utilized in rural development to achieve success. The study sought to establish how far the aspects of learning are applied as strategies for project implementation by religious organizations. The need for change is crucial in delivering a project. For example, to tackle a disease such as ebola a community might need rapid change while tackling cancer might need long-term gradual change. Project implementation strategies are get influenced by the urgency of the change and it will be crucial to test how the project implementation strategies of religious organizations take into consideration urgency of change.

Resources are never enough, and availability of local resources is another crucial aspect on delivering projects. Local resources are crucial in the implementation of projects. The research sought to establish how well religious organizations map out and leverage on local resources to deliver effective rural development. In this area it will be crucial to determine how religious organizations complement the local resources rather than replicating. Project implementation would not be complete without measuring. Measurement is crucial in project implementation, especially, to determine early wins, changes needed and lasting impact. As part of the research, the study sought to determine how religious organizations ensure measurement is well done when implementing projects. It is also important to undertake risk mitigation. In project management it is crucial to mitigate against various risks. These risks will be both internal and external. The research sought to identify how well religious organizations cater for risks while implementing projects.

\section{Theoretical Framework}

The theory of decentralization as expounded by Rondenalli [22] will inform this study. According to him, decentralization has demonstrated potential to lead to more appropriate and better-utilized facilities, lower unit costs of services and improved operations and maintenance. As regards equity and efficiency in utilizing scarce national resources, these are important issues, which cannot be secured solely by local decision-making, as conflicts of interests between different localities are always present. But without a decentralized structure, there would not be adequate administrative channels for implementation, local ownership of programs, coordination and for collection of necessary local data for policy formulation.

According to Rondenalli [22] decentralization is necessary for making development plans realistic and for adapting projects, policies and programs to the needs of local people. The main aim of the decentralization has been to strengthen the capacity of local authorities to deliver services to its residents. More importantly, decentralization helps to create the capacity to assume responsibility at local level. Real and lasting improvements in poverty alleviation will only happen if local authorities involve their residents in decision making about how and where resources are used, remain accountable to their citizens for those decisions and their results [23].

Decentralization enables people to participate more directly in planning and management of development projects. It helps empower people previously excluded from decision-making. In this way a country creates and sustains equitable opportunities for its entire people. Closer contacts between church officials and administrators and between local communities, institutions/organizations, encourage 
exchange of information that can be used to formulate development programmes that are tailored to local needs and priorities and thus attain more effective and sustainable development [17]. This study sought to establish to what extent these decentralization tenets are embedded in the implementation of projects by religious organizations and the subsequent influence on rural development. The relationship between Catholic Church development activities and rural development measured by the socio economic indicators of the levels of poverty will be based on this concept.

The stakeholder theory has evolved and according to the stakeholder theory done in 2006 looking at multinational corporations [3] there are over stakeholder participation is an evolving theory and it is best described based on the prevailing circumstances and the environment under study. The theory applied also depends in detail to the nature of institution that is being studied. In general, the agreement is that stakeholders are those who come into contact with a project directly or indirectly and it is crucial to note that there will be those with more stake than others and they form a critical part of ensuring success or failure of a project.

\section{Conceptual Framework}

The conceptual framework used in the research was to provide a comprehensive explain the variables and the relationships. This is shown in Fig. 1.

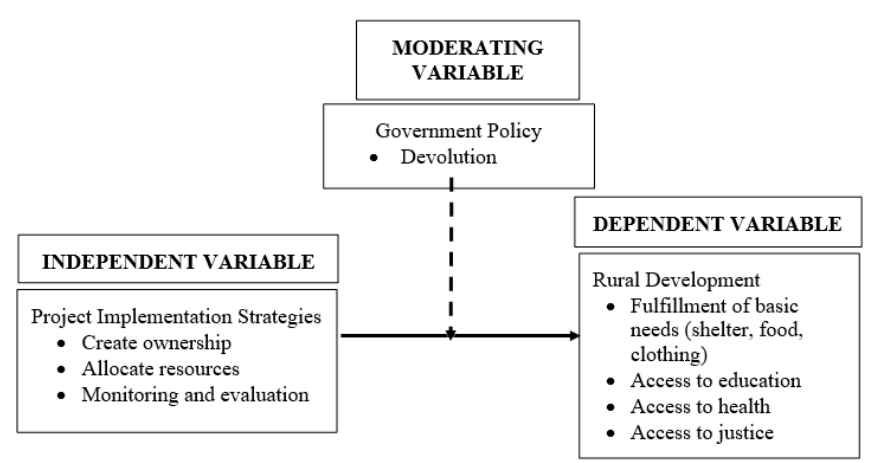

Fig. 1. Conceptual Framework.

\section{RESEARCH METHODOLOGY}

\section{A. Research Design}

The study utilized descriptive research survey design study where the researcher sought to answer the questions from of what, when, where, when and how. The question on why was responded to through inference, which was made out of the study results. Descriptive research was involved with the accurate description of variables in the problem formulated. According to Cooper and Schindler [24], descriptive surveys target populations with an effort to find out who, what, when, where, and how within the precincts of a topic. Kerlinger [25] indicates that descriptive studies are not restricted to fact-finding but can also result in the formulation of important solutions to significant problems. Descriptive design involves the measurement, classification, analysis, comparison, and interpretation of data. Orodho [26] defines descriptive survey as "a method of collecting information by interviewing or administering a questionnaire to a sample of individuals".

Descriptive survey focuses on identifying opinions habits or other social issues. The descriptive survey design also sought to discover certain characteristics and associations between variables. It is also used to make specific predictions, according to Malhotra [27]. The methods typically used in a descriptive study could be surveys, panels, observations, or secondary data analysed in a quantitative manner [27].

The target population was households in the proposed sub-county out of 8 sub-counties in the Catholic diocese of Kitui area of jurisdiction. Heads of households were sampled and where he/she was not available, any family member above the age of eighteen years was sampled. To achieve practicability, the study targeted households respectively in the Nzambani and Chuluni wards. The population in Kitui county was mainly homogenous and the researcher also sought to apply the results across board in the county as well as Kenya since the focus was the Catholic church which has also homogeneity across the country. Nzambani has 5 locations and Chuluni has 6 locations. This means that the study allocated $50 \%$ of its target population in Nzambani ward and 50\% in Chuluni ward and further spread the target population into 5 villages in Nzambani and in 6 villages in Chuluni ward. In addition, the study targeted government officials, community based organisations, religious organisations and Catholic Diocese of Kitui management staff.

\begin{tabular}{cc}
\multicolumn{2}{c}{ TABLE 1: TARGET POPULATION } \\
\hline Category & Target population \\
\hline Households in Nzambani & 3599 \\
Households in Chuluni & 3340 \\
Catholic diocese of Kitui staff & 6 \\
Government employees & 13 \\
\hline Total & 6966 \\
\hline Source: KNBS [28]
\end{tabular}

The study adopted systematic sampling techniques in selecting household respondents from the two (2) wards. The points chosen were the ward headquarters. These wards had a mixed population with urban, peri-urban and rural households. The number of households in the two wards is 6750 (source: Kenya National Census 2009). If we apply a population growth rate of $2.8 \%$, which was projected at the time of the census, the projected number of households is 6939. This is the number that researcher utilized to develop the sample size. In addition to the households, the researcher sought out to interview a representative number of government and Catholic Diocese of Kitui staff. In total, the study sampled 383 respondents arrived at using Krejcie and Morgan table. The table below presented the target group in detail.

TABLE 2: SAMPLE SIZE

\begin{tabular}{cccc}
\hline \multicolumn{4}{c}{ TABLE 2: SAMPLE SIZE } \\
\hline Households & \multicolumn{3}{c}{} \\
\hline \multirow{2}{*}{ Ward } & $\begin{array}{c}\text { Target } \\
\text { population }\end{array}$ & $\begin{array}{c}\text { Sample size } \\
(5.25 \%)\end{array}$ & $\begin{array}{c}\text { Total Sample } \\
\text { Size }\end{array}$ \\
\hline Nzambani & 3599 & 188.95 & 189 \\
Chuluni & 3340 & 175.35 & 175 \\
Subtotal & 6939 & & 364 \\
Catholic diocese of Kitui staff & 6 & 6 & 6 \\
Government employees & 13 & 13 & 13 \\
\hline Total & & 383 & 383 \\
\hline
\end{tabular}


Using the Krejcie and Morgan table, the researcher sampled a total of 364 households, which represents $5.25 \%$ of the total households in the two wards. The researcher further applied systematic sampling so as to select the households to be interviewed. Further, the study sought to target all Catholic Diocese of Kitui middle level and senior management staff totaling 6 as well as 13 government representatives working in the sampled areas. The 13 government representatives were the village administrators and two ward administrators. In total, the study sampled 383 respondents.

The main research instrument that was used in this study was a questionnaire. In developing the questionnaire items, the fixed choice and open-ended formats of the item was used. This format was used in all categories of the questionnaires. Most of the items adopted a Lickert scale (1 - strongly disagree, 2 - disagree, 3 - undecided, 4 agree, 5 - strongly agree). An interview guide was used to collect data from the management staff of the Catholic Diocese of Kitui. The researcher also made use of interview guides so as to allow for more information gathering especially when dealing with the staff of the government and the Catholic Diocese of Kitui.

The research used the test and retest model to pilot the instruments in Kitui West, Kabati Ward. This allowed for the instruments to be reviewed and corrected before the actual survey. The choice of the test area was to ensure there is consistency since the Kabati has the similarities with the proposed study area in terms of population and settlement patterns.

The content validity of the instrument was determined in two ways. First the researcher discussed the items in the instrument with the supervisors, lecturers from the department and colleagues. Advice given by these people helped the researcher determine the validity of the research instruments. The advice included suggestions, clarifications, and other inputs. These suggestions were used in making necessary changes. Secondly, content validity of the instrument was determined through piloting, where the responses of the subjects were checked against the research objectives. This also gave a reason as to why content had to be used. For a research instrument to be considered valid, the content selected and included in the questionnaire must be relevant to the variable being investigated Mutai [29]. The researcher performed the pilot test Kitui West, Kabati Ward, on 4 government officials, 4 Roman Catholic management staff and 12 households. Appropriate changes were made on the research instruments depending on the responses.

The researcher used the test and retest reliability model to ensure that the tools are fit for purpose. In order to test the reliability of the instrument to be used in the study a pilot study was carried out and a reliability coefficient computed. This established the extent to which the questionnaire elicits the same responses every time it was administered. A correlation coefficient of 0.7 was considered reliable for the study as per Orodho [26] recommendations. The results obtained from the pilot study assisted the researcher in revising the questionnaire to make sure that it covers the objectives of the study.
Research assistants working in those sampled regions were thoroughly trained both in interpretations of responses from respondents and also in the procedure of administration. They then accompanied the researcher in piloting and modifying the research instruments so that they could comprehend fully the purposes and methods of data collection. The research assistants administered the questionnaires personally to the respondents and were the ones entering responses from the respondents in the questionnaire. The researcher however administered the interview guide to government officials directly. This enabled him gather additional information and interpret answers based on the research objectives.

After data collection, questionnaires were checked for completeness and consistency of information at the end of every field data collection day and before storage. Data capturing was done using Excel software. The data from the completed questionnaires was cleaned, re-coded and entered into the computer using the statistical package for social sciences (SPSS) for Windows for analysis. Data analysis and the findings were reported in chapter four.

Descriptive statistics (that is frequency analysis) were computed for presenting and analyzing the data. Descriptive statistics enabled the researcher to describe the aggregation of raw data in numerical terms [30]. The descriptive statistics used involve the use of univariate, bivariate and multivariate analyses. These methods incorporated the use of frequency distributions, percentage tables and measures of central tendency. They also incorporated the use of measures of variation such as: ranges, arithmetic mean, percentiles, and standard deviations for univariate analysis. Data was presented in the form of frequency distribution tables and that facilitated description and explanation of the study findings.

Inferential statistics was employed where the chi-square test was used to test whether there is a relationship between Roman Catholic development activities and rural development.

\section{FINDINGS}

The researcher administered 364 questionnaires to the households and 19 questionnaires to management staff. Out of this only 262 households and 15 management staff returned fully filled questionnaires as shown in Table 3. This represented a response rate of $71.9 \%$ and $78.7 \%$ respectively which conformed to [1], who stated that a questionnaire return rate of 50 percent is adequate for analysis.

TABLE 3: QUESTIONNAIRE RETURN RATE

\begin{tabular}{lcc} 
& No. of Informants & $\begin{array}{c}\text { Questionnaire } \\
\text { Return Rate }\end{array}$ \\
\hline Households & 364 & 262 \\
Catholic Diocese of Kitui & 6 & 5 \\
management staff & 13 & 10 \\
Government employees & 383 & 277 \\
Total & & \\
\hline
\end{tabular}




\section{A. Reliability Analysis}

Reliability of the questionnaire was evaluated through administration of the said instrument to the pilot group. The acceptable reliability coefficient is 0.7 and above [13]. A construct composite reliability co-efficient (Cronbach alpha) of 0.7 or above, for all the constructs, is considered to be adequate for this study. The results were as shown in Table 4.

\begin{tabular}{|c|c|c|}
\hline & Cronbach's alpha & Decision \\
\hline Project implementation expertise & .711 & Reliable \\
\hline Project implementation strategies & .778 & Reliable \\
\hline $\begin{array}{l}\text { Project implementation funds } \\
\text { allocation }\end{array}$ & .701 & Reliable \\
\hline Stakeholder involvement & .833 & Reliable \\
\hline Rural Development & .742 & Reliable \\
\hline
\end{tabular}

From the results, stakeholder involvement was more reliable with an alpha value of 0.833 , followed by project implementation strategies with an alpha value of 0.778 , then rural development with an alpha value of 0.742 , then project implementation expertise with an alpha value of 0.711 while project implementation funds allocation with an alpha value of 0.701 had the least reliability. This, therefore, depicts that the research instrument was reliable, and no amendments were required.

\section{B. Background Information}

The researcher was interested in the respondents' general information including their gender, age bracket, highest educational level, marital status, occupation, and average annual income in Kshs. Their responses were as presented in subsequent subsections.

\section{Gender of the Respondents}

The researcher was interested in establishing gender distributions of the Catholic Diocese of Kitui and County Government of Kitui management staff. The findings are as indicated in Table 5.

TABLE 5: GENDER OF THE RESPONDENTS

\begin{tabular}{lcc}
\multicolumn{3}{c}{ TABLE 5: GENDER OF THE RESPONDENTS } \\
\hline & Frequency & Percent \\
\hline Male & 8 & 53.3 \\
Female & 7 & 46.7 \\
Total & 15 & 100.0 \\
\hline
\end{tabular}

From the results, majority of the respondents were male as shown by $53.3 \%$ while the rest were female as illustrated by $46.7 \%$. This implies that the researcher obtained reliable information from all the respondents regardless of the gender.

\section{Age Bracket of the Respondents}

The household heads were also asked to indicate their age brackets. Their responses were as presented in Table 6 .

\begin{tabular}{lcc}
\multicolumn{3}{c}{ TABLE 6: AGE BRACKET OF THE RESPONDENTS } \\
\hline Less than 25 years & Frequency & Percent \\
26-35years & 58 & 22.1 \\
36-45years & 38 & 14.5 \\
46-55 years & 54 & 20.6 \\
More than 55 years & 60 & 22.9 \\
Total & 52 & 19.8 \\
\hline
\end{tabular}

From the findings, $22.9 \%$ of the household heads were 46-55 years, $22.1 \%$ were less than 25 years, $20.6 \%$ were 36 45years, $19.8 \%$ were more than 55 years while $14.5 \%$ were 26-35years. This implied that majority of the households were mature enough to cooperate in giving out information being sought.

\section{E. Marital Status of the Respondents}

The respondents were asked to indicate their marital status. Their responses were as shown in Table 7.

TABLE 7: Marital Status of THE MANAGEMENT STAFF AND HOUSEHOLD HEADS

\begin{tabular}{lcc}
\hline & Frequency & Percent \\
\hline Married & 79 & 28.4 \\
Single & 64 & 23.0 \\
Divorced & 65 & 23.4 \\
Widowed & 70 & 25.2 \\
\hline Total & 278 & 100 \\
\hline
\end{tabular}

The research findings revealed that $28.4 \%$ of the management staff and household heads were married, $25.27 \%$ were widowed, $24.4 \%$ were divorced while $23 \%$ were single. This implies that majority of the respondents were married.

\section{F. Respondents' Highest Level of Education Achieved}

The researcher requested the respondents to indicate their highest level of education. Their responses were as shown in Tables 8 and 9

TABLE 8: HigheSt LEVEL OF EDUCATION ACHIEVED By THE

\begin{tabular}{|c|c|c|}
\hline \multicolumn{3}{|c|}{ MANAGEMENT STAFF } \\
\hline & Frequency & Percent \\
\hline College & 7 & 46.7 \\
\hline University & 8 & 53.3 \\
\hline Total & 15 & 100.0 \\
\hline
\end{tabular}

From the results, $53.3 \%$ of the management staff had reached the university while $46.7 \%$ had reached college. This implies that the management staff was learned enough and could comprehend the subject under study and hence they gave correct information.

TABLE 9: HigheSt LEVEl of EduCATION ACHIEVED By THE HouseHOLd HEADS

\begin{tabular}{ccc}
\hline & Frequency & Percent \\
\hline Not educated & 4 & 1.4 \\
Lower primary & 30 & 10.8 \\
Upper primary & 53 & 19.1 \\
Junior secondary Form 1-2 & 57 & 20.6 \\
Senior Secondary Form 3-4 & 49 & 17.7 \\
College & 7 & 2.5 \\
University Undergraduate & 54 & 19.5 \\
University Post graduate & 23 & 8.3 \\
\hline Total & 277 & 100
\end{tabular}

The findings also show that $20.6 \%$ of the management staff and household heads had reached junior secondary form $1-2,19.1 \%$ had reached upper primary, $17.7 \%$ had reached senior secondary form 3-4, $19.5 \%$ had reached university undergraduate level, $10.8 \%$ had reached lower primary level, $8.3 \%$ had reached the university post graduate level, $2.5 \%$ were college graduates while $1.4 \%$ were not educated. This implies that majority of the household heads had gotten basic education and could understand the questionnaire. 


\section{G. Occupation of the Household Heads}

The research further required the household heads to indicate the occupation in which they were. The results were as shown in Table 10.

TABLE 10: OCCUPATION OF THE HOUSEHOLD HEADS

\begin{tabular}{ccc}
\hline & Frequency & Percent \\
\hline Teacher & 57 & 21.8 \\
Farmer & 42 & 16.0 \\
Pastoralist & 43 & 16.4 \\
Civil Servant & 58 & 22.1 \\
Businessman/woman & 62 & 23.7 \\
Total & 262 & 100.0 \\
\hline
\end{tabular}

The findings also reveal that $23.7 \%$ of the household heads was a businessman/woman, $22.1 \%$ were civil servants, $21.8 \%$ were teachers, $16.4 \%$ were pastoralists while $16.0 \%$ were farmers. This implies that all the respondents had an occupation.

\section{H. Respondents' Average Annual Income in KSHS}

The household heads were also required to indicate their average annual income in Kenya Shillings. Table 11 displays the results.

TABLE 11: RESPONDENTS’ AVERAGE ANNUAL INCOME IN KSHS.

\begin{tabular}{ccc}
\hline & Frequency & Percent \\
\hline Less than 10,000 & 50 & 19.1 \\
$10,000-20,000$ & 70 & 26.7 \\
$20,000-40,000$ & 79 & 30.2 \\
$40,000-80,000$ & 36 & 13.7 \\
$80,000-160,000$ & 17 & 6.5 \\
$160,000-320,000$ & 9 & 3.4 \\
More than 320,000 & 1 & .4 \\
Total & 262 & 100.0 \\
\hline
\end{tabular}

The findings revealed that $30.2 \%$ of the household heads earned an average of Kshs.20,000-40,000, 26.7\% earned between Kshs.10,000-20,000, 19.1\% earned less than Kshs. 10,000, $13.7 \%$ earned between Kshs. 40,000-80,000, 6.5\% earned between Kshs. 80,000-160,000, 3.4\% earned between Kshs.160,000-320,000 while $0.4 \%$ earned more than Kshs. 320,000. This implies that majority of the household heads do not earn much.

\section{Rural Development}

The researcher required to know the list of activities carried out by Catholic Diocese of Kitui to enhance rural development. The respondents indicated that the Catholic Diocese of Kitui conducted training services, provided income generation activity, started projects for construction of primary schools, executed a forest/watershed conservation project Small-scale Irrigated, and began an agriculture promotion. The research further required the respondents to indicate the social needs that they concentrated on mostly. Table 12 shows the results.

TABLE 12: Social NeEDS THAT ARE MOSTly CONCENTRATED ON

\begin{tabular}{ccc}
\hline & Frequency & Percent \\
\hline Water & 4 & 26.7 \\
Food & 3 & 20.0 \\
Shelter & 2 & 13.3 \\
Roads & 2 & 13.3 \\
Health & 1 & 6.7 \\
Education & 1 & 6.7 \\
Income generation & 2 & 13.3 \\
Total & 15 & 100.0 \\
\hline
\end{tabular}

The findings also reveal that $26.7 \%$ of the management staff indicated that they concentrated on water, $20.0 \%$ indicated food, $13.3 \%$ indicated shelter, $13.3 \%$ indicated roads, $13.3 \%$ indicated income generation, $6.7 \%$ indicated health while $6.7 \%$ indicated education.

The respondents further gave their suggestions to improve Catholic Diocese of Kitui's contribution to rural development. They indicated that by reviewing of the church development activities will bring forth a deeper comprehension of local needs and identifying area resources to have a better perception on which needs to address first; church should seek collaboration with other churches in development sectors; and to boost people's moral and trust, the government of Kenya to seek partnership with churches to achieve its development visions.

From the interviews, the county officials, and Catholic Diocese of Kitui were asked to state how the concept of decentralization been used in implementing projects by the Catholic Diocese of Kitui. They indicated that decentralization has enabled accountability for the implementation of its tasks and also has increased the level of citizen participation in making major decisions and directly affecting the community. They also added that the local communities have been somewhat supporting especially in water projects but are not yet able to take over, manage and sustain projects started by Catholic Diocese of Kitui.

The respondents also indicated that there have been withdrawal strategies once Catholic Diocese of Kitui projects reach maturity. These included transfer of ownership to some locals. Regarding the challenges that Catholic Diocese of Kitui encountered in implementing projects, the respondents indicated lack of clear goals and success criteria; lack of communication; budgeting issues; inadequate skills of team members; lack of accountability; and inadequate risk management.

The respondents also made suggestions to make government agencies and Catholic Diocese of Kitui improve performance in implementing projects. They also indicated that the staff from the Catholic Diocese of Kitui had the necessary competence to engage in development. This is confirmed by one of the interviewees who commented:

"The staff of the Catholic Diocese of Kitui are very professional and are keen to listen to us when they visit."

An interviewee from the county government also indicated the importance of the cordial working relationship with the Catholic Diocese of Kitui being attributed to the level of professionalism:

"When we undertake county planning, we call upon the Catholic Diocese of Kitui to give input since they are involved in implementing projects at the local level and they do it professionally".

They indicated that the government agencies and Catholic Diocese of Kitui should stay focused on their main goal; improve project planning and quality; stay in touch with the local community more often; have good communication channels; and prioritize team members' tasks. 


\section{J. Project Implementation Strategies and Rural Development}

The research aimed at examining the influence of project implementation strategies by Catholic Diocese of Kitui on rural development in Kitui County. The researcher required the management staff to indicate the extent to which Catholic Diocese of Kitui project implementation has affected the following indicators of rural development. The participants were requested to indicate with: Strongly Disagree $=1$; Disagree $=2 ;$ Undecided $=3$; Agree $=4$; Strongly Agree =5; The results are as set out in Table 4.19.

\begin{tabular}{|c|c|c|c|c|c|c|c|}
\hline & 1 & 2 & 3 & 4 & 5 & Mean & $\begin{array}{l}\text { Std. } \\
\text { Dev. }\end{array}$ \\
\hline $\begin{array}{l}\text { The projects have } \\
\text { improved food supply }\end{array}$ & $\begin{array}{c}0 \\
(0)\end{array}$ & $\begin{array}{c}0 \\
(0)\end{array}$ & $\begin{array}{c}2 \\
(13.3)\end{array}$ & $\begin{array}{c}12 \\
(80)\end{array}$ & $\begin{array}{c}1 \\
(6.7)\end{array}$ & 3.933 & 0.958 \\
\hline $\begin{array}{l}\text { The projects have led to } \\
\text { improvement of nutrition }\end{array}$ & $\begin{array}{c}0 \\
(0)\end{array}$ & $\begin{array}{c}1 \\
(6.7)\end{array}$ & $\begin{array}{c}1 \\
(6.7)\end{array}$ & $\begin{array}{c}1 \\
(6.7)\end{array}$ & $\begin{array}{c}12 \\
(80)\end{array}$ & 4.600 & 0.910 \\
\hline $\begin{array}{l}\text { They have enhanced } \\
\text { increases in income }\end{array}$ & $\begin{array}{c}2 \\
(13.3)\end{array}$ & $\begin{array}{c}2 \\
(13.3)\end{array}$ & $\begin{array}{c}4 \\
(26.7)\end{array}$ & $\begin{array}{c}1 \\
(6.7)\end{array}$ & $\begin{array}{c}6 \\
(40)\end{array}$ & 3.467 & 0.506 \\
\hline $\begin{array}{l}\text { They project have } \\
\text { enhanced increased access } \\
\text { to justice }\end{array}$ & $\begin{array}{c}3 \\
(20)\end{array}$ & $\begin{array}{c}3 \\
(20)\end{array}$ & $\begin{array}{c}5 \\
(33.3)\end{array}$ & $\begin{array}{c}2 \\
(13.3)\end{array}$ & $\begin{array}{c}2 \\
(13.3)\end{array}$ & 2.800 & 0.820 \\
\hline $\begin{array}{l}\text { The project has improved } \\
\text { access to Health services }\end{array}$ & $\begin{array}{c}0 \\
(0)\end{array}$ & $\begin{array}{l}0 \\
(0)\end{array}$ & $\begin{array}{c}0 \\
(0)\end{array}$ & $\begin{array}{c}3 \\
(20)\end{array}$ & $\begin{array}{c}12 \\
(80)\end{array}$ & 4.800 & 0.914 \\
\hline $\begin{array}{l}\text { The projects have } \\
\text { facilitated improvement in } \\
\text { access to education }\end{array}$ & $\begin{array}{c}0 \\
(0)\end{array}$ & $\begin{array}{c}0 \\
(0)\end{array}$ & $\begin{array}{c}1 \\
(6.7)\end{array}$ & $\begin{array}{c}12 \\
(80)\end{array}$ & $\begin{array}{c}2 \\
(13.3)\end{array}$ & 4.067 & 0.958 \\
\hline $\begin{array}{l}\text { Composite Mean and } \\
\text { Standard deviation }\end{array}$ & & & & & & 3.945 & 0.844 \\
\hline
\end{tabular}

The findings revealed that the $12(80 \%)$ strongly agreed that the project has improved access to Health services and $3(20 \%)$ agreed. The statement had a mean of 4.800 and standard deviation of 0.914 which was higher than the composite mean of 3.945 and standard deviation of 0.844 , implying that project has improved access to Health services.

On the statement that the projects have led to improvement of nutrition, 1(6.7\%) disagreed with the statement, 1(6.7\%) were undecided, 1(6.7\%) agreed with the statement and 12(80\%) strongly agreed with the statement. The statement had a mean of 4.600 and standard deviation of 0.910 which was higher than the composite mean of 3.945 and standard deviation of 0.844 , implying that projects have led to improvement of nutrition.

Regarding the statement that the projects have facilitated improvement in access to education, 1(6.7\%) were undecided with the statement, 12(80\%) agreed with the statement and $2(13.3 \%)$ strongly agreed with the statement. The statement had a mean of 4.067 and standard deviation of 0.958 which was higher than the composite mean of 3.945 and standard deviation of 0.844 , implying that projects have facilitated improvement in access to education. Further to this an interviewee had the following to say in relation to meeting their needs:

"We are grateful to the Catholic Diocese of Kitui for providing health facilities across our area hence helping in reducing our agony and distances to the hospitals."

On statement that the projects have improved food supply, 2(13.3\%) were undecided with the statement, $12(80 \%)$ agreed with the statement and $1(6.7 \%)$ strongly agreed with the statement. The statement had a mean of
3.933 and standard deviation of 0.958 which was higher than the composite mean of 3.945 and standard deviation of 0.844 , implying that projects have improved food supply.

Moreover, on statement that projects have enhanced increase in income, 2(13.3\%) strongly disagreed with the statement, 2(13.3\%) disagreed, 4(26.7\%) were undecided, $1(6.7 \%)$ agreed and 6(40\%) strongly agreed with the statement. The statement had a mean of 3.467 and standard deviation of 0.506 which was less that the composite mean of 3.945 and standard deviation of 0.844 , implying that it's not clear if projects have enhanced increase in income.

On statement that project have enhanced access to justice, 3(20\%) strongly disagreed with the statement, $3(20 \%)$ disagreed with the statement, 5(33.3\%) were undecided with the statement, $2(13.3 \%)$ agreed with the statement, 3(20\%) strongly agreed with the statement. The statement had a mean of 2.800 and a standard deviation of 0.820 which was less that the composite mean of 3.945 and standard deviation of 0.844 , implying that it's not clear if project have enhanced access to justice.

\section{K. Inferential Statistics}

The study conducted both the chi-square and the multiple regression analysis. The regression analysis was used to establish the relations between the independent and dependent variables while correlation was conducted to assess the degrees of association between the variables.

\section{Chi Square Test}

The Chi square test was done to establish the relationship between the project implementation strategies by religious organizations on rural development in Catholic Diocese of Kitui, Kitui County. The findings are as shown in Table 14.

\begin{tabular}{lccc}
\multicolumn{3}{c}{ TABLE 14: CHI-SQUARE TESTS } \\
\hline & Value & df & $\begin{array}{c}\text { Asymptotic significance } \\
\text { (2-sided) }\end{array}$ \\
\hline Pearson chi square & 8.954 & 266 & 0.003 \\
Continuity & 8.448 & 266 & 0.004 \\
$\begin{array}{l}\text { correction } \\
\text { Likelihood ratio }\end{array}$ & 8.928 & 266 & 0.003 \\
\hline
\end{tabular}

The Chi-Square test results of the association between project implementation strategies by religious organizations and rural development at Catholic Diocese of Kitui, Kitui County in Table 14, shows a Chi-Square value $=8.954, \mathrm{p}=$ 0.003. The p-value is less than 0.05 and hence there is a statistically significant association between project implementation strategies and rural development at Catholic Diocese of Kitui, Kitui County. This meant that the project implementation strategies significantly promote the rural development at Catholic Diocese of Kitui, Kitui County.

\section{Multiple Regression Analysis}

This section of the study presents the results and discussions of the regression output. In order to examine the impact of relationship between project implementation strategies and rural development in Kitui County, regression model was estimated. The regression analysis enables the researcher to empirically test the proposed hypothesis and to achieve the research objective. Tables 15-17 display the findings. 


\begin{tabular}{ccccc}
\multicolumn{5}{c}{ TABLE 15: MODEL SuMMARY } \\
\hline Model & $\mathrm{R}$ & R Square & $\begin{array}{c}\text { Adjusted R } \\
\text { Square }\end{array}$ & $\begin{array}{c}\text { Std. Error of the } \\
\text { Estimate }\end{array}$ \\
\hline 1 & 0.839 & 0.705 & 0.700 & 0.424 \\
\hline
\end{tabular}

From the findings, Table 15 is a model fit which establish how fit the model equation fits the data. The adjusted $\mathrm{R}^{2}$ was used to establish the predictive power of the study model and it was found to be 0.700 implying that $70.0 \%$ of the variations in rural development in Kitui County are explained by changes in project implementation strategies.

TABLE 16: ANOVA

\begin{tabular}{|c|c|c|c|c|c|c|}
\hline & Model & $\begin{array}{c}\text { Sum of } \\
\text { Squares }\end{array}$ & Df & $\begin{array}{c}\text { Mean } \\
\text { Square }\end{array}$ & $\mathrm{F}$ & Sig. \\
\hline \multirow{3}{*}{1} & Regression & 113.566 & 4 & 28.392 & 156.315 & $3.74 \mathrm{E}-68$ \\
\hline & Residual & 47.587 & 262 & 0.182 & & \\
\hline & Total & 161.153 & 266 & & & \\
\hline
\end{tabular}

The probability value of $3.74 \mathrm{E}-68$ indicates that the regression relationship was highly significant in predicting how project implementation strategies influenced rural development in Kitui County. The F calculated at 5 per cent level of significance was 156.315. Since F calculated is greater than the F-critical (value $=2.4061$ ), this shows that the overall model was significant.

TABLE 17: REGRESSION COEFFICIENTS

\begin{tabular}{|c|c|c|c|c|c|c|}
\hline & \multirow{2}{*}{ Model } & \multicolumn{2}{|c|}{$\begin{array}{c}\text { Unstandardized } \\
\text { Coefficients }\end{array}$} & \multirow{2}{*}{$\begin{array}{c}\begin{array}{c}\text { Standardized } \\
\text { Coefficients }\end{array} \\
\text { Beta }\end{array}$} & \multirow{2}{*}{$\mathrm{T}$} & \multirow{2}{*}{ Sig. } \\
\hline & & $\mathrm{B}$ & $\begin{array}{l}\text { Std. } \\
\text { Error }\end{array}$ & & & \\
\hline & (Constant) & 3.537 & 0.505 & & 7.004 & 0.000 \\
\hline 1 & $\begin{array}{c}\text { Project } \\
\text { implementation } \\
\text { strategies }\end{array}$ & 0.843 & 0.333 & 0.885 & 2.532 & 0.012 \\
\hline
\end{tabular}

The regression equation obtained from this outcome was:

$$
-\mathrm{Y}=\mathbf{3 . 5 3 7}+\mathbf{0 . 8 4 3 \mathrm { X } _ { 1 }}
$$

From the findings, the study found that if the independent variable, project implementation strategies, was held constant at zero, then the rural development in Kitui County will be 3.537 .

The study also found that a unit change in project implementation strategies changes would lead to a 0.843 unit change in rural development in Kitui County. The variable was significant since $\mathrm{p}$-value $=0.012<0.05$. Overall, project implementation strategies had a great influence on rural development in Kitui County.

[14] argues that the strategies of religious organizations are anchored on the presence an existence on the local communities. This means that religious organizations respond and work within the structures of the local communities to the large extent. They have also been known to be the originators of ideas that serve local needs. Religious organizations through these approaches to rural development have played a key role in the growth of the social enterprise and social business movements. The study found that the project had improved access to health services; and had led to improvement of nutrition. The research also revealed that the projects had facilitated improvement in access to education; and had improved food supply. Moreover, the projects had enhanced increase in income; and had increased.

The research also sought the benefits that that the project implementation strategies had on the community. The study found that the Catholic Diocese of Kitui projects had enabled most children access education and had led to improved food supply in the area. The research also found that it was not certain whether local people now had improved nutrition due to Catholic Diocese of Kitui Projects; the Catholic Diocese of Kitui projects had enabled most local residents access and afford health services; due to improved levels of income, access to education and health services, the people had an improved quality of life as a result of Catholic Diocese of Kitui projects; and if the local community was able to utilize resources better and get more returns from their use. The findings conform to [11] who stated that project implementation would not be complete without measuring. Measurement is crucial in project implementation specially to determine early wins, changes needed and lasting impact. As part of the research, the study sought to determine how religious organisations ensure measurement is well done when implementing projects. It is also important to undertake risk mitigation. In project management it is crucial to mitigate against various risks. These risks will be both internal and external.

\section{CONCLUSIONS}

The study deduced that project implementation strategies have a positive and significant influence on rural development in Kitui County.

The research concluded that the Catholic Church is actively involved in project implementation activities enhancing community cohesiveness. This enables project members to live together while sharing common norms and values necessary for successful project implementation and development.

\section{RECOMMENDATIONS}

The study recommends

1. That there is need for capacity development to identify resource availability and build capacities in communities and have them assisted to undertake church based projects. Though priests may be involved as project managers due to trustworthiness, there should be considerations that those who have appropriate project management as well as soft human relation skills are more suitable.

2. Funds management is a critical function in all community based projects since it influences rural development in Kitui County, the study recommended that projects leaders and development partners need to emphasize and undertake training on proper management of funds. It is also recommended that sources of finances be made known by the managers to create accountability and transparency. This would enable stakeholders to feel that there is top management support to financial allocation and sustainability as opposed to the current feeling.

3. Since stakeholder participation is significant to rural development in Kitui County, the study recommends that 
development agencies and project leaders should strive to sensitize community participation in community based development projects. To create more ownership of the projects, the study recommends that there should be involvement of user representatives from the initiation to the implementation phases of the projects. This will erase a feeling that these are alien projects which are meant to benefit the initiators and the church alone. A sense of ownership and or belonging is vital to success of the existing and any future church projects.

\section{REFERENCES}

[1] Babbie, E. (2015). The Practice of Social Research.

[2] Babu, S and Asenso-Okyere, K. (2010). Innovation programs are working for the poor.

[3] Fontaine, Haarman and Schmid, (2006). Stakeholder Theory.

[4] Hickey, Sam at el. (2003). Relocating participation within a radical politics of development: citizenship and critical modernism. University of Manchester.

[5] Karingi, S. (2001), Fiscal Policy for Poverty Reduction Case Study Revenue Design: The Kenyan Experience. Kenya institute for public policy research and analysis.

[6] Kirubi, M. (2006). Rural poverty, decentralization and development. Business school: Nanjing Normal University.

[7] Malcom H. and Alison E. (2003). Conceptual Framework I, Implementation of Medium Term Expenditure Framework.

[8] Mackenzie, F. and Taylor, D. (1987). District Focus as a Strategy for Rural Development in Kenya: The Case of Murang'a District, Central Province. Canadian Journal of Development Studies.

[9] Mugenda, A. and Mugenda, O (1999). Research Methods: Qualitative and Quantitative Approaches. Nairobi: Acts Press.

[10] Mwangi, J. and Nyang'wara, B. and Ole Kulet, J. (2015). Factors Affecting the Effectiveness of Monitoring and Evaluation in Constituency Development Fund Projects in Kenya: A Case of Laikipia West Constituency, Kenya.

[11] Requena (2016). Evolution of the concept and policy of rural development with emphasis in its early years (1955-1980).

[12] Shepherd, F. (1993). Church and State in Honduras and Nicaragua Prior to 1979 (pp).

[13] Song et al, (2014). Determining the drag coefficient of a cylinder perpendicular to water flow by numerical simulation and field measurement.

[14] Spear, R. (2007), Religion and Social Entrepreneurship.

[15] Stadel, C. (1995), Development Needs and the Mobilization of Rural Resources in Highland Bolivia.

[16] Suzen (2017). Drivers of the Failure in Management of the Illegal Immigration Crisis in Europe. Beyond the Horizon.

[17] UNDP (2000). The UNDP role in Decentralization and Local governance: A joint UNDP-Governance project of Germany Evaluation.

[18] Varshney, A. (1999): "Democracy and Poverty". Paper for the Conference on world Development Report 2000 The World Bank.

[19] Yirenkyi, Kwasi. (2000). The Role of Christian Churches in National Politics: Reflections from Laity and Clergy in Ghana (pp).

[20] Zadawa and Omran, (2019). Rural Development in Africa: Challenges and Opportunities.

[21] Zyl, J. and Barbosa, T. and Parker, A. and Sonn, L., (1995). Decentralized Rural Development and Enhanced Community Participation: A Case Study from Northeast Brazil.

[22] Rondenalli, D. (1983) Implementing decentralization programmes in Asia: A comparative analysis

[23] Richard, C. (2000): Decentralization and poverty in Africa.

[24] Cooper and Schindler (2003): Business Research Methods.

[25] Kerlinger, F. N. (1969): Foundations of behavioral research: education and psychological inquiry.

[26] Orodho (2003): Essentials of Educational and Social Science Research Methods.

[27] Malhotra, N. K. (2004): Marketing Research.

[28] KNBS (2019): Kenya Economic Survey Report 2018.

[29] Mutai, K. B. (2000): How to write quality research proposals.

[30] Neuman 2000: Social research methods qualitative and quantitative approaches. 4th Edition. 